\title{
Fiodor Michajlovič Dostojevskij - téma a postava
}

\author{
Viera Žemberová (Prešov)
}

\begin{abstract}
Abstrakt
Text sa sústredil na vybrané autorské zámery na približenie osobnosti Fiodora Michajloviča Dostojevského. Tri knižné práce sa odlišným žánrovým spôsobom venujú vybratým úsekom zo života Dostojevského. Jadro žánrovej odlišnosti spočíva v genologickej problematike pri troch textoch, ktoré pracujú s faktom a fikciou. O žánrovej forme rozhodli dostupný materiál a dokumenty, s ktorými sa pracuje, a tendencia poskytnút historickú biografiu, autorskú rekonštrukciu ako zaujímavú, či výnimočnú konkrétnu sekvenciu zo života alebo literárny príbeh na sprostredkovanie lúdského portrétu známeho spisovatel'a.

\section{Kl'účové slová}

dejiny; spoločnost', genius loci; materiál; fikcia; rekonštrukcia; rozprávanie; osobnost' autora

Abstract

\section{Fiodor Mikhailovich Dostoevskij - Theme and Character}

The text focused on selected authors' intentions to bring the personality of Fiodor Mikhailovich Dostoyevsky closer to him. Three books are devoted to selected sections of Dostoevsky's life in a different genre. The core of genre difference lies in the genological issue of three texts that work with fact and fiction. The genre form was decided by the available material and documents that are being worked on and the tendency to provide a historical biography, an authorial reconstruction as an interesting or exceptional specific sequence from life or a literary story to convey the human portrait of a famous writer.
\end{abstract}

\section{Key words}

history; society; genius loci; material; fiction; reconstruction; narration; author's personality 
„Najuäčšim štastím pre spisovatel'a je, ked’ sa nepokladá za zuláštneho, osamelého, ale ked' je taký ako ostatni l’udia. “

Michail Prišvin

V prvej polovici šesṫdesiatych rokov minulého storočia sa k čitatel’om dostala v slovenskom preklade pozoruhodná publikácia Konstantina Paustovského Zlatá ruža s doplňujúcim podtitulom Poznámky o spisovatelovej práci. Podnet na vydanie výberu z Paustovského, na zážitok intenzívneho a štylisticky i spôsobom výkladu kultivovaného spôsobu vyrovnávania sa - súčasne vzdelávania tých, ktorí sa začítajú do Zlatej ruže - s poznaním európskej literatúry, s ruskou klasickou spisbou a súčasne s podmanivým vnášaním informácií o vlastnej tvorbe od raných veršovaných počiatkov až po zrelú prozaickú tvorbu sa stali Sobranije sočinenija, ich druhý zväzok ${ }^{2}$. Zvoleným postupom Konstantin Paustovskij ${ }^{3}$ oslovuje čitatela viacerými komornými informáciami o sebe a zmysle, väčšmi o poslaní publikácie, a aby nenastalo nezosúladenie sa medzi čitatel’ovým očakávaním vloženým do názvu Zlatá ruža, pozýva čitatela prostredníctvom ním skomponovaného retazca zaujímavých príhod do autorských dejín predovšetkým francúzskej, anglickej, ruskej a sovietskej literatúry ${ }^{4}$. Početnými kultúrnymi odkazmi navracia sa do kultúrnej pamäti dvoch predminulých storočí ruskej a európskej literatúry, zaujímavými podobenstvami naznačuje prepojenia moderných národných literárnych spoločenstiev, odkazuje na porozumenie svetu krásnej literatúry a jej tvorcu: „Táto kniha nie je teoretickým pojednaním, tým menej príručkou. Sú to proste poznámky o mojich skúsenostiach a o tom, ako ja chápem literatúru. Mnohých oblasti ideových základov našej spisovatel'skej práce sa v knihe nedotýkam [...]. Hrdinský a výchovný význam našej literatúry je každému jasný“. Koná tak preto, že jeho výlučnou ambíciou je „dat' čitatel'ovi predstavu o nádhernej podstate spisovatel'skej práce“, ked' uspeje s týmto zámerom, potom bude mat' istotu, „že som splatil svoj dlh literatúre“5. Kapitolu Zdanlivé maličkosti ${ }^{6}$ začína Paustovsky takto: „Skoro každý spisovatel' má vlastný zdroj inšpirácie, svojho dobrého ducha - obyčajne to býva tiež nejaký spisovatel ${ }^{\times / 7}$. Dôvodí, na potvrdenie tézy o podmanivosti a rozvíjaní aj o postupnom prirodzenom osamostatňovaní sa talentovaného autora od raných „medziautorských kontaktov“, odkazmi na viacero intenzívnych inšpirácií z osobných tvorivých dejín, aby sa venoval aj Dostojevskému. Na počiatku

1 PAUSTOVSKIJ, Konstantin: Zlatá ruža. Poznámky o spisovatelovej práci. (Sobranije sočinenija, tom 2. Moskva, 1957). Prel. Ružena Dvořáková-Žiaranová. Verše prebásnil Viliam Turčány. Doslov Umením o umeni nap. Ondrej Marušiak. Bratislava: Slovenské vydavatel'stvo krásnej literatúry, 1963.

2 PAUSTOVSKIJ, Konstantin: Sobranije sočinenija, tom 2. Moskva: Gosudarstvennoje izdatel'stvo chudožestvennoj literatury, 1957.

3 Konstantin Georgijevič Paustovkij (1892 Moskva - 1968 Moskva). Literárne práce spravidla uvádzal pod menom Konstantin Paustovsky: poézia, próza, dramatická tvorba a scenaristika.

4 Paustovskij do kapitoly Dávno zamýšlaná kniha sústredil svoje (autorské) výklady literárnych dielní s názvami Čechov, Alexander Blok, Guy de Maupassant, Maxim Gorkij, Victor Hugo, Michail Prišvin, Alexander Grin, Eduard Bagrickij. In: PAUSTOVSKIJ, Konstantin: Zlatá ruža. Op, cit., 1963, s. 275-319.

5 PAUSTOVSKIJ, Konstantin: Zlatá ruža. Op. cit., 1963, úvodná čast̉ bez názvu a číslovania strany, opatrená citátom autorov Saltykov-Ščedrin a Hororé de Balzac.

6 Zdanlivé maličkosti. In: K. Paustovskij: Zlatá ruža. Op. cit., 1963, s. 185-207.

7 Tamže, s. 185. 
pripomenie toto, „Dostojevskij a Byron, ktorí radi pracovali v noci, prehrešovali sa proti svojmu talentu“8. A pokračuje vážnejšou informáciou, ktorá obsiahne aj hodnotiaci moment: „Ťažkosti Dostojevského tvorivej práce netkveli, prirodzene, len v tom, že pisaval po nociach a pritom sa stále nalieval čajom. To sa koniec-koncov ani vel'mi neodzrkadlilo na kvalite jeho práce. Ťažkosti boli v tom, že sa Dostojevskij nemohol vymotat' z finančnej krizy a z dlhov, a preto musel pisat' vel'mi mnoho a vždy napochytre. Do práce sa priberal vždy v poslednej chvíli. Ani jedno zo svojich diel nenapisal pokojne a s plným rozmachom. Svoje romány väčšinou odflákol - nie čo do počtu napisaných strán, ale pokial' ide o rozvláčnost'. Preto sa mu nevydarili tak, ako pôvodne zamýšlal. Omnoho príjemnejšie je snívat’ o románe, ako ho pisat', vravieval Dostojevskij. [...] Dlhy ho nútili pisat', hoci neraz, ked' sa púštal do písania, si uvedomoval, že román ešte nedozrel. Kol'ko myšlienok, obrazov a podrobnosti vyšlo nazmar jedine preto, že mu zišli na um príliš neskoro, ked' už bol román hotový, alebo podl'a jeho mienky, nenapravitel'ne pokazený! Núdza ma núti náhlit' sa a pisat’ pre peniaze, čiže nevyhnutne dielo kazit', hovorieval o sebe Dostojevskij" ${ }^{\text {"9. }}$.

Skutočnost, že sa osobnost’ spisovatel’a sama stáva látkou a tematikou textu iného autora, žiada si genologickú vol’bu a odpoved', aký žáner sa dokáže presvedčivo vyrovnat s osobnostou, tvorbou, spoločenskými a kultúrnymi dejinami, ktoré autora vymedzujú, určujú a poskytujú dobový hodnotiaci prístup k jeho osobnosti a jeho umeleckej tvorbe. Žánre epiky a žánre literárnej vedy poskytujú niekolko podnetných možností, tak spravidla vzniká kompromis vo forme žánrového hybridu, ktorý sa musí vyrovnat’ s faktom a fikciou, dokumentom a beletrizáciou reálií napojených na súkromie aj na tvorbu osobnosti spisovatel'a posunutého do roly subjektu, teda literárnej postavy. Ústredným predpokladom na to, aby vznikol rešpektovaný text o verifikovatel’nej osobnosti dobového spoločenského a literárneho života sú dôkladné znalosti o nej aj o možnostiach genológie na realizáciu literárneho zámeru „vytvorit““ literárny portrét alebo príbeh o tom, koho kultúrne spoločenstvo, jeho skúsenost’ a pamät, pozná z jeho tvorby. Prirodzené, dôveryhodné a primárne vyhladávané zázemie vytvára materiál, autentický aj sprostredkovaný, najčastejšie ide o denník, záznamník, korešpondenciu, zápisy, správy, spontánne reakcie alebo literárne rozhovory, d’alej o spomienky z druhej a tretej ruky, o kontakt s pamätou rodiny, o rozlične napojených príbuzných, priatel’ov, vydavatel’ov, redaktorov, prekladatel’ov, literárnych historikov, biografistov a pokračovat možno v súčasnosti až po vymoženosti a žánre vytvorené technickou a mediálnou súčasnostou, čo by znamenalo horizontálne rozširovanie foriem, ako možno získavat’ verbálne a neverbálne, priame aj sprostredkované výpovede o zvolenej osobnosti.

Autor publikácie Život Alexandra Puškina ${ }^{10} \mathrm{v}$ časti Od autora upozorňuje na to, že sa autor zámeru „ocitá pred nevyhnutnostou vymedzit’ si hranice biografie ako žánru“, že ide o inú volbu, akú by poskytli žánre literárnej vedy, a to preto, lebo „V strede životopiscovej pozornosti musi byt' spisovatelova osobnost', jej svojráznost', jej podmienenost' okolitou skutočnost'ou, historickými udalostami. Hlavným prameňom [...] je [...] spisovatel'ova pôsobnost', zakotvená v jeho

8 Tamže, s 201.

9 Tamže, s. 201-202.

10 MEJLACH, Boris S.: Život Alexandra Puškina. (Chudožestvennaja literatura. Leningrad, 1974). Prel. Jozef Marušiak. Bratislava: Slovenský spisovatel', 1974, s. 277. 
literárnom dedičstve. Ale umelecká tvorba sa musi v biografii skúmat’ z určitého zorného uhla ako odraz autorovej individuality a vývoja jeho svetonázoru, jeho ohlasov na požiadavky súčasnosti, ako stelesnenie ciel’ov, ktoré si staval pred seba on sám"11. Zo životopiscovej inštrukcie, za takého sa označil Boris S. Mejlach, plynie, že sa výberom žánru a metódou na literárne organizovanie verifikovatelného príbehu a života ruského umelca rozhodol tak, že zvolil na čo najprecíznejšiu rekonštrukciu života všestranne talentovaného A. S. Puškina a jeho denník, ktorý si Puškin (1799-1837) zapĺn̆al zápiskami v dvadsiatych rokoch devätnásteho storočia.

Pred výberom žánru, ktorý by umožňoval sprostredkovat’ autorom to, čo získal z rozličných prameňov a zdrojov o Fiodorovi Michajlovičovi Dostojevskom ${ }^{12}$, vediac o nemalom množstve pokusov vyrovnat sa s jeho osobnostou, stáli aj Leonid Grossman ${ }^{13}$, Anna Grigorievna Dostojevská ${ }^{14}$ a Leonid Cypkin ${ }^{15}$. Leonid Grossman mal zámer vytvorit z materiálu, ktorý mal k dispozícii, príbeh s románovým rámcovaním, Anna Dostojevská, druhá manželka spisovatel’a, spracovala osobnú a rodinnú spomienku na spoločných štrnást̉ rokov, na počiatku stál román Hráč, na manžela, otca a spisovatela Dostojevského a Leonid Cypkin nasmeroval svoje rozprávanie na dramatickú sekvenciu zo života manželov Dostojevských počas ich cesty po Európe a pobytu v kúpeloch v Baden-Badene.

Ústredným podnetom na tematizovanie a „príbehové“ personalizovanie Fiodora Dostojevského v role postavy v naračných žánroch rozličnej aj odlišnej morfológie, ktoré sa stretajú v dominantných a autorsky aj spoločensky dramatických priesečníkoch jeho osobného, rodinného, spoločenského či literárneho života (odsúdenec//spisovatel', hráč) a odlišnou empatiou sa dotýkajú / objasňujú zložitú osobnost̉ Dostojevského, aby sa ukotvili pri traumách plynúcich pre neho a jeho blízke okolie z jeho hráčskej vášne. V každom z aktualizovaných troch textov zohráva karbanícka závislost’ spisovatel'a inú rolu, má odlišnú osobnú, časovú, priestorovú, spoločenskú motiváciu, teda aj spôsob jej aktualizovania má vzdialené následky a odlišne objasňovanú tendenciu podnetov získaných „z druhej ruky“ na porozumenie osobnosti Dostojevského. Iniciácie zotrvávajú pri jeho literárnej adaptácii vo svojich žánroch pevne zachytené v spisovatel’ovej osobnostnej traume, v dráme aj v tragédii, rekonštrukcia psychologickej a sociálnej, rodinnej a vzṫahovej krízy sa podriad’uje, ale je aj limitovaná, tendencii narácie, teda organizovaniu časového a tvorivého torza zo života Dostojevského, ale približujú sa predovšetkým hodnote dokumentu - materiálovým podnetom na sprostredkovanú rekonštrukciu, na spomínanie a beletrizovanie toho, ako to bolo, kde to bolo, s kým to bolo a čo z toho vzniklo

11 Tamže, čast' Od autora, s. b. č.

12 Fiodor Michajlovič Dostojevskij (1881 Petrohrad - 1881 Moskva).

13 Leonid Petrovič Grosssman (1888 Odesa - 1965 Moskva); Leonid Grossman: Dostojevskij. (Chudožestvennaja literatura. Moskva - Leningrad, 1932). Prel. Emília Drugová. Bratislava: Tatran, 1979.

14 DOSTOJEVSKÁ, A. G.: Život s Dostojevským. Prel. Ladislav Zadražil. Praha: Odeon, 1981; DOSTOJEVSKÁ, A. G.: Spomienky. Prel. Mária Hulmanová. Bratislava: Európa, 2009.

15 Leonid Borisovič Cypkin (1926 Minsk - 1982 Moskva); CYPKIN, Leonid: Léto v Baden-Badenu. (Leonid Tsypkin: Summer in Baden-Baden, 1981; Moskva, 2003). Překlad a doslov Jakub Šedivý. Praha: Prostor, 2015. 
v jeho živote a o akú nadčasovú hodnotu ide v kultúrnych dejinách humanizovaných spoločenstiev.

Leonid Grossman rozložil svoju rekonštrukciu osobnosti a autorskej genézy Dostojevského do európskeho ponapoleonského priestoru a skomponoval ju z tridsiatich deviatich sekvencií; naračne skutočne ide o príbehové miniatúry na osi kompozične rámcujúceho a tendenčného (mal materiál) oživovania dejinného a osobného času mladého Dostojevského a kontinentálneho priestoru (Francúzsko, Nemecko, Švajčiarsko) s ruským geografickým priestorom (zvlášt petrohradské obdobie). Tému a postavu zapájania mladého absolventa cárskeho vojenského inžinierstva Dostojevského do európskeho a petrohradského politického a spoločenského života začína Leonid Grossman detailným opisovaním osláv Napoleonovej porážky a odkazmi na známe spoločenské a politické reálie života na kontinente a objasňovaním postoja vítazných mocností už odkazuje na oslavovanú udalosṫ napojenú na personálne zásluhy o bitku pri Waterloo. Pripomínaním Napoleonovej tragédie na získanie kontinentu na mieste jeho poslednej prehry a tematickým udržiavaním napolenského motívu, jeho ruskej sekvencie ako odrazovej dejinnej „plochy“ na všetko a pre všetkých, ktorí v dobe genézy literárnej budúcnosti Dostojevského sa pohybovali v jeho blízkosti v Petrohrade, neskôr aj sporadicky v Moskve, alebo ide o tých, ktorí vedia o jeho hráčskom počínaní si v mladosti aj v čase manželstva s Annou v nemeckom kúpel'nom Baden-Badene. Grossmanovi materiál určil a poskytol dostatok podnetov na chronológiu rekonštrukcie začiatkov vojenského inžiniera Dostojevského v Petrohrade a držal ju dovtedy v mikroepizódach, kým ho dostupný materiál povzbudzoval, potom sa Grossman rozhodol pre beletrizovanie sekundárnych podnetov, na ktoré sú viaceré biografie venované Dostojevskému bohaté. Leonid Grossman preruší kompozičnú schému z rámcovaného času (teraz a vtedy) a venuje sa viacerým osobným skúsenostiam či príhodám z osobných dejín a denníkových zápisov spisovatela. Spomedzi členov rodiny venuje sekvenciu Dostojevského bratovi Michajlovi Michajlovičovi ${ }^{16}$ a okolnostiam okolo vydávania a zániku periodika Vremja ${ }^{17}$. Leonid Grossman do úplnosti rekonštrukcie Dostojevského mladosti, ktorá mu je dožičená dostupným materiálom, aktualizuje jeho osobné a literárne kontakty, spory s cárskou mocou, venuje sa spisovatelskej a spoločenskej nevraživosti (Nekrasov, Turgenev) voči nemu v petrohradskom literárnom živote, zachytáva jeho nelahké erotické kontakty so svetom žien, osobné citové traumy z telesného vzhl’adu, mužské poníženia ním obdivovaných žien, ktoré museli prirodzene prenikat do jeho vedomia a sebavedomia. Ale Leonid Grossman poskytuje aj Dostojevského rané úvahy o literatúre, filozofovanie iniciované zložitými okolnostami jeho nekončiacich útrap osamelého muža s nekončiacim nedostatkom finančných prostriedkov, obnovuje jeho rozlične vznikajúce, udržiavané i zanikajúce spoločenské a osobné kontakty tak, aby často a ilustračne funkčne citoval z jemu dostupných zdrojov a tými sú predovšetkým početné spisovatelove denníky ${ }^{18}$. Tam, kde Grossmanovi neposkytujú

16 Michajl Michajlovič Dostojevskij (1820-1864).

17 Periodiká, do ktorých Dostojevskij prispieval: Vremja (1861-1863), Epocha (1864-1865).

18 Preklady Dostojevského denníkov začali vychádzat v češtine v Prahe u vydavatela Jana Laichtera: Denik spisovateli̊v $I .-I V$. v rokoch 1910 až 1912. Po viacerých vydaniach, ktoré sledovali len konkrétny rok zapísaný v denníku, vydali v pražskom Odeone v roku 1977 v preklade Ladislava Zadražila Denik spisovatele II. 
dostupné dokumenty na udalosti a ich beletrizovanie vhodnú zásobnicu d’alších epizód, púšta sa do detailne organizovaných opisov citových a psychických stavov a do priebehu a predovšetkým do prejavov Dostojevského hráčskej vášne, pritom mottom či svojím komentárom v zátvorke odkazuje na jeho prozaické texty, kde sa takto získaná skúsenost’ stáva súčastou literárneho príbehu (román $H r a ́ c c^{19}$ ), aby povýšil na pointu univerzálnu tézu: „Ak má človek vytvorit’ vel'ké umelecké dielo, musí doň vložit’ celý svoj život, so všetkým, čo prinútilo jeho úbohé srdce zvierat' sa a chviet', so všetkými ostrými, úmornými, slastnými dojmami, so všetkými bolestnými urážkami, trpkými sklamaniami, letmými útechami z bledých a chabých úsmevov, ktoré nám pohrdlivo a roztržito pohodi život, taký pozorný a neúprosný pri uštedrovaní úderov, bodnuti a rán. Musi doň vložit' celý život, alebo aspoň najnezabudnutelnejšie časti tohto monotónne sa rozvijajúceho tkaniva, na niekol'kých miestach roztrhnutého neúprosným ostrím katastrof, neštastí a otrasov. Z toho sa rodia nesmrtelné knihy..." ${ }^{20}$.

Významná časṫ Grossmanovej „rekonštrukcie“ počiatkov Dostojevského literárnej a spoločenskej prítomnosti v petrohradskom umeleckom prostredí sa venuje vážnejšej udalosti, akou sa azda aj ako obrana voči existenciálnemu prežitku dostaví ako hráčska závislost', je ňou obvinenie, vypočúvanie, odsúdenie, prežitý akt popravy, vyhnanstvo s väzením a tažkou prácou; to všetko postretlo tridsiatnika Dostojevského ako dôsledok obvinenia cárskou políciou z účasti na tajnom spolkovom živote v cárovom meste a na príprave atentátu. Grossmanova rekonštrukcia dôkladne a efektívne sleduje spôsob cárskeho policajného a justičného systému, ale aj správanie sa Dostojevského v jeho život ohrozujúcej situácii, čím premyslene vkladá svoju literárnu kapitolu do spoločenských dejín krajiny, ktorá sa mocou vyrovnávala so všetkým a všetkými, ktorí narušovali chod cárskeho systému a jeho predstavitel'ov. Grossman sa rozhodne aj pre d’alší ústretový krok voči čitatelovi, každú z takmer štyroch desiatok epizód uvádza formou motta, sú to rozlične iniciované a zakomponované odkazy na prozaikove romány, na čast̉ textu prijatého od iného autora, na torzo citovaného listu, rozhovoru, či inak do kontextu vstupujúcej sekvencie z udalostí doby a kontinentu, ktoré vytvorili kulisu pre dobové Rusko a Dostojevského. Leonid Grossman vymedzil v rekonštrukcii rolu aj pre seba, pracuje s vel'kým počtom graficky zvýraznených zátvoriek v rekonštruovanom texte o časti života ruského spisovatela, v nej dopovedúva, vysvetluje, pripomína, alebo kladie nepriamu otázku samotnej literárnej postave Dostojevského. Aj preto opakovane upozorňuje na jeho vzdelanie cárskeho vojenského inžiniera, ktoré získal pre potreby cárovej armády. Návraty k Napoleonovi („aký historický zmysel mali Napoleonove výpravy“21), k udalostiam

a v Olomouci vo vydavatel'stve Votobia, v preklade Václava Koeniga v roku 1996 Denik spisovatelưv: za rok 1880-1881. V slovenčine vydali v preklade Valerija Kupka a Ivany Kupkovej vo vydavatel’stve Európa dva tituly: Z Dennika spisovatela v roku 2008 a Rusko a Európa. Z Dennika spisovatel'a v roku 2010.

19 „V obdobi proního pobytu v zahraniči v letech 1862-1863 se zrodil zámèr románu Igrok, který byl napsán až v r. 1866 a vydán s podtitulem Zapiski molodogo čeloveka. Román má výrazné znaky autobiografické a krouži kolem otázky zhoubného pưsobení peněz“. In: Kol. autorů: Slovnik ruských spisovatelů od počátků ruské literatury do roku 1971. Heslo Dostojevskij Fjodor Michajlovič. Praha: Lidové nakladatelství, 1972, s. 65.

20 GROSSMAN, Leonid: Dostojevskij. (Chudožestvennaja literatura. Moskva - Leningrad, 1932). Prel. Emília Drugová. Bratislava: Tatran, 1979, čast' Zrodenie obrazu, s. 253-254.

21 Tamže, čast' Generál Scharnhorst, s. 15. 
okolo Waterloo („tvár Západu sa zmenila a história vykročila na novú cestu“22), slávnostné odhalenie pamätného obelisku na poctu tejto udalosti spôsobia, že tieto sekvencie spoločne prerastajú osobný a komorný rámec Dostojevského života a roky osobnostného prebúdzania sa do tvorivej aj tragickej sekvencie aprílových nepokojov ${ }^{23}$, čím Leonid Grossman vo svojej stratégii literárneho textu o ruskom spisovatel’ovi napovedá, že sa v cárskom Rusku udalosti z Napoleonovho ataku na krajinu z desiatych rokov postupne navracajú v inej podobe, s inými nositel’mi a krajinu znova čaká krutá skúška a odvaha na prežitie zložitých spoločenských udalostí a konkrétnych dejov. Autor Leonid Grossman o nich z dejín dvadsiateho storočia vie, a vie, čo doniesla budúcnost̉ Rusku a jeho spoločnosti. Grossmanov záujem o osobnost̉ mladého Dostojevského v publikácii dopĺňajú cenné a v beletrizovanom čítaní nie všedné dokumenty v troch komentovaných „obrazových prílohách“ z osobného a rodinného zázemia, čo napovedá o ambicióznom a účinnom žánrovom aj naračnom koncepte celku Grossmanovej rekonštrukčnej práce odvodenej od kategórie dejinného a osobného času, tie ako problém zakomponoval do petrohradskej mladosti a do európskych cestovatel'ských potuliek osamelého Fiodora Michajloviča Dostojevského. A to všetko v čase, ked’ prozaika naliehavo znepokojujú myšlienky na sociálnu revolúciu, ale aj pohrávanie sa s predstavou samovraždy či túžbou po telesnej kráse, aby preniklo do „príbehu“ postupné ujasňovanie si osobného spisovatel'ského poslania, ktoré v osobnom živote očakával, pripravoval sa naň a písal o ňom, aby vedome i týmto spôsobom vzdoroval a odmietal zlo.

Naisto najdôveryhodnejšie pôsobia a v kultúrnom vedomí sa udržiavajú tie spomienky na osobnost', ktoré poskytne kultúrnej verejnosti najbližšia a blízka osoba z čias ich spoločného života alebo zo spolupráce. Jedno i druhé zo žitej skutočnosti s Dostojevským obsahujú autentické spomienky jeho manželky Anny Grigorievny. Intenzita zážitku z pohybu po ukončení života a uzavretí sa spisovatelovho diela, ako ich v čírej intímnej, rodinnej, kultúrnej a spoločenskej rovine zachytila Anna Grigorievna Dostojevská v Spomienkach, prinášajú nielen rozpomienky, ale aj rekonštrukcie viacerých podstatných udalostí zo spoločného života, z členitej rodiny, zo zložitých vzájomných vztahov a z okolo vzniku literárnych textov, čím sa stáva personalizovaná autentická spomienka iniciáciou na približovanie sa k tomu, čo Anna Grigorievna prijímala, vložila a uchovala zo štrnástich rokov spoločného života s Fiodorom Michajlovičom Dostojevským: „Nikdy predtým som sa nezaoberala myšlienkou napisat’ svoje spomienky. Okrem toho som si uvedomila, že nemám nijaké literárne vlohy, a celý život som bola tak intenzívne zaujatá vydávaním diela svojho nezabudnutel’ného muža, že mi ledva zvýšil čas na to, aby som sa postarala o iné záležitosti späté s jeho pamiatkou“24. Tému osobnej spomienky Anna Dostojevská začína svojím stenografickým školením, prácou stenografky pre Dostojevského v postavení, ktorým si zarábala na živobytie a osamostatnenie sa, pokračuje sobášom, štrnástimi rokmi spoločného života, zmienkami o spoločných detoch a uzatvára ich úmrtím Dostojevského. Pod touto časovou horizontálou vytvorila rozprávačka sugestívne mikrobloky z povahy a spoločenských

22 Tamže, s. 11.

23 Tamže, čast’ Apríloví vzbúrenci, s. 109-116.

24 DOStOJEVSKÁ, A. G.: Predslov (k Spomienkam). In: DOSTOJEVSKÁ, A. G.: Spomienky. Op. cit., s. 7. 
prejavov zložitej osobnosti Dostojevského. Pri akejkolvek zmienke o ňom prejavuje mu nežnosṫ, pripomenie jeho sklon k viere a žiarlivost', nepraktickost̉ a neschopnosṫ zbavit sa príživníkov spomedzi svojej širšej rodiny. Spoločne s rozprávačkou spomienok možno sledovat intímne aj spoločenské okolnosti, ktoré vyvoláva Dostojevského zničujúca choroba. Anna Dostojevská ju prijíma vyrovnane ako skutočnost', ktorej sa možno bránit, ale nemožno pred ňou uniknút. S nostalgiou si obnovuje udalosti zo spoločných ciest po zahraničí a s pokorou pomocníčky spisovatela naznačuje odlišné rodinné, finančné, spoločenské situácie, ktoré negatívne vstupovali do života rodiny a frustrujúco účinkovali v Dostojevského literárnej práci na románoch i ním založeného časopisu. Spomienky manželky sa venujú rovnakým tónom, vždy s nežným nadhladom, porozumením a s odstupom k nežičlivým okolnostiam, ktoré znova a opätovne iniciovali, napríklad po stavke, nový a d’alší záväzný termín na odovzdanie nového a d’alšieho románu vydavatelovi.

Spisovatela Dostojevského neobchádzali rozlične motivované aj (ne)doriešené osobné konflikty, početné spoločenské nedorozumenia, ale i ním vyžadované prejavy uznania či obdivu. Takmer po celý spoločný život sa stali dlžoby hnacím motorom všetkého, čím jeho rodina žila; tie sa ku skonu spisovatela podarilo Anne vyrovnat a oslobodit rodinu od tejto zátaže a potupy. V Spomienkach sa Dostojevská opakovane vracia k románom Idiot, Diablom posadnutí, Zločin a trest, Bratia Karamazovci, pripomína Dostojevského zložitý osobný kontakt s Nekrasovom, iný býval s Turgenevom a jeho želanie zoznámit sa s Levom Tolstým. Dostojevského prozaická tvorba a články pre Ruský vestník, Čas, Epochu majú pre Annu Grigorievnu v Spomienkach podobu (ná)tlaku na dodržanie termínu a na doručenie autorských hárkov vydavatelovi. Manažérsku prácu okolo distribúcie spisovatelovej tvorby a pri získavaní finančných prostriedkov, aby sa aspoň na čas zmiernili ich sociálne problémy, vykonávala Anna ako svoje osudové poslanie v manželovom výnimočnom živote. Spomienky sú príjemným a ústretovým pripomínaním si milovaného manžela, na jednej strane velikána ruskej literatúry, na druhej strane povahou zložitého partnera a milujúceho otca. Anna Grigorievna ani raz nevykročila svojím spomínaním do blízkosti teórie a estetiky Dostojevského textu, najskôr aj preto, lebo oddane dôverovala jeho príbehu a plastickosti postáv, kompozičnej role konfliktov aj spôsobom ich riešení, ktoré zapisovala a o čom spolu hovorili. V spomienkach na rok 1877 si zapísala toto: „Č́m vä̌řsmi sa približoval koniec roka, tým častejšie sa Fiodor Michajlovič zamýšlal nad otázkou, či má v budúcom roku pokračovat vo vydávani Dennika spisovatela. So ziskom z tohto vydávania bol muž úplne spokojný; aký úprimný a dôverčivý vztah mali $k$ nemu čitatelia, odráža sa v listoch, ktoré mu pisali, a v nespočetných návštevách neznámych l’udí čo si velmi vážil, ale potreba venovat' sa vlastnej tvorbe prevážila a Fiodor Michajlovič sa rozhodol prerušit vydávanie Dennika spisovatela na dva-tri roky a začat nový román. Na to, aké literárne zámery zaujímali a vzrušovali môjho muža, dá sa usudzovat' z poznámkového notesa, do ktorého si 24 . decembra roku 1877 zapisal: „Memento. - Na celý život. 1, Napisat' ruského Candida./ 2. Napisat’ knihu o Ježišovi Kristovi./ 3. Napisat' svoje spomienky./ 4. Napisat poému Spomienková modlitba na štyridsiaty deň po smrti. (Všetko to, okrem posledného románu a zamýślaného Dennika, je minimálne desat' rokov práce, a teraz mám pätdesiatšest' rokov)“25. 
Spomienka sa mení na prítomnostnú rekonštrukciu reality v okamihoch odchádzania Dostojevského, ked’ Anne povie: „Nie, ja viem, že musím dnes zomriet. Zapál' sviecu, Aňa a daj mi Bibliu! ${ }^{\text {'26 }}$ Spomienky na ruského spisovatel’a, manžela, otca svojich detí, na zložitú osobnost', ktorá by neobstála v skutočnosti bez jej podpory, ukončila smrt’ a ustálila oddaný vztah k vytvoreniu spoločenského mýtu o Fiodorovi Michajlovičovi Dostojevskom.

Anna Dostojevská v Spomienkach zaznamenala, že s manželom bývali v európskych kúpeloch. Pôsobivá rekonštrukcia pobytu spisovatela s manželkou v Baden-Badene si našla svojho rozprávača v Leonidovi Cypkinovi ${ }^{27}$. Ten priblížil Dostojevského z odvrátenej strany, no súčasne aj s podnetom „z druhej ruky“. Cypkin sa venuje letnému pobytu manželov Dostojevských v nemeckom kúpel’nom mestečku, ale ústredná pozornost̉ patrí Petrohradu, mestu, v ktorom sa stretajú dva časy, preto aktivuje prítomnosł́ a naráciu dvojakých rozprávačov a epicentrom ich rozprávania sa stali detailne rekonštruované nepríjemné spoločenské zážitky ruských manželov, cudzincov s obmedzenými finančnými prostriedkami, s odlišným vztahom $\mathrm{k}$ rodinnému finančnému problému, $\mathrm{k}$ existencii a dôsledkom spisovatelovho karbaníctva. Kým sa Cypkinovo rozprávanie rozvinie: „Manželé Dostojevští odjeli z Petrohradu v polovině dubna roku 1867 a už následujicího rána dorazili do Vilniusu“28, Anna si všimne miestnych „židáčkư“, aby osvedčenou cestovatelskou trasou prišli do Berlína, potom do Drážd’an a do Baden-Badenu. Spoločenské, sociálne a návykové strety s nemeckým prostredím neznáša Anna dobre, uvedomuje si, že Nemci, „obzulášt pak Němky [...] nové ruské hosty nemilosdrdně odírali, špatne krmili, čísnici je šidili při vraceni drobných [...], ale Němci vưbec byli národ nechápavý..."29. Spôsob, akým rozprávač mapuje prvé kontakty Dostojevských s nemeckým prostredím napovedá, že tonalita jeho prístupu k dokumentu si uchová vecnost', hoci aj on si pozorne prečítal Annin Život s Dostojeuským ${ }^{30}$, ktorý „Anna Grigorievna napsala krátce préd revolucí, patrně po seznámeni s Leonidem Grossmanen, se už o židáčcich na schodišti nezmiñuje). Na fotografii vlepené do Deniku vypadá Anna Grigorievna, tenkrát ještě dočista maličká, jako fanatička nebo jako pobožnůstkářka s nevraživým zamračeným pohledem “31. Rozprávanie o Anne a Fiodorovi Dostojevských „z druhej ruky“ je opatrené dostupným autentickým materiálom a literárnohistorickou či biografickou znalostou sprístupnených dokumentov, spomienkami, rozprávaniami, ktoré vzišli spomedzi odborníkov, literátov a súčasníkov ruského spisovatela. Napätá expozícia Cypkinovho textu, zvýrazňovanie negatívneho postoja Rusov voči neruskému okoliu a vice versa, odkazy na fotodokumentáciu, na doplnenie knižného vydania Léta v Baden-Badenu (2015) o popisnú dokumentáciu tých obydlí v Petrohrade, kde sa Dostojevský zdržiaval a ten skutočne často menil v meste svoje adresy, čo naznačuje, že v Cypkinovom etnicky ladenom koncepte sa na beletrizovaný „obal“ dostane aj

26 Tamže, s. 318. V záverečnej časti Spomienok Dostojevská oživuje ich vzájomnú dôveru, úctu a možnost̉ prežit spoločné roky "v štastí, aké je l’ud’om dopriate na zemi prežit", nečíslovaná strana (v poradí 348).

27 Leonid Cypkin (1926-1982), novely Most přes Něroč (1973), Norartakis (1976).

28 CYPKIN, Leonid : Léto v Baden-Badenu. Op. cit., s. 10.

29 Tamže.

30 DOSTOJEVSKÁ, A. G.: Život s Dostojevským. Praha: Odeon, 1981.

31 CYPKIN, Leonid: Léto v Baden-Badenu. Op. cit., s. 11. 
„faktografická“ rekonštrukcia jediného, ale zvnútra demaskovaného vztahu manželov Dostojevských počas ich liečebného pobytu v kúpel’och. Rozprávačove sympatie obídu manželov a pri presune do minulého storočia a do dávneho Petrohradu sa sústredí na tých jeho obyvatelov a na tú, jemu najbližšiu ženu spomedzi ruských židov, ktorí prežili blokádu Leningradu, a vel'komesto sa rozhodlo pomenovat jednu z ulíc po spisovatel'ovi: „Přistoupil jsem těsně $k$ domu - na ceduli visící na rohu bylo napsáno: ulice Dostojevského, ale já jsem ji chtěl z nějakého důvodu považovat za Povoznickou, jak se nazývala, než ji přejmenovali - šel jsem kolem tohohle domu po Povoznické ulici..."32. Ambíciu detailne v čase a v priestore bádenských letných kúpel’ov, ich urbanistického prepojenia na nevel'ké nemecké mesto s navštevovanou herňou pri železničnej stanici prerozpráva rozprávač ako retazenie sa nepokojných príhod v správaní sa manželov. Situačné krízy ich vztahu vyjadruje bezmocnosṫ slabej vôle spisovatel'a a silného citu Anny, ked' bezmocne ustupuje pred Fiodorovovou závislostou. V iniciácii vypovedá prozaik Cypkin „z druhej ruky“ pravdu uloženú do dokumentov, zápisov, do spomienok o neduhu prozaika, ale súčasne v realistickom sociálne, psychologicky, emotívne a mravne zložitom spolužití chce zobrazit’ odlišné typy manželov a hĺbku ich vzájomného vztahu, ktorý trpel spisovatelovým karbaníctvom, nezodpovednostou, cholerickou povahou a vážnou chorobou. Spomienky „z druhej ruky“ sú „Výsledkem mnohaletého Cypkinova studia Dostojevského dila, vzpominek jeho současniků a návštěv mist spjatých s tímto obdivovaným spisovatelem je zcela výjimečná kniha nejen o Dostojevském a jeho myšlenkovém světě, ale rovněž o lásce Anny Grigorievny k jejímu Fed'ovi a v neposledni řadě i o době, ve které žil sám autor Léta v Baden-Badenu“"33. Autorský záujem Leonida Cypkina sa zúročuje v návrate spisovatela k spisovatel’ovi: „Cypkin za svého života jako spisovatel v podstatě neexistoval, ačkoli dnes se jeho dílo řadi mezi klasická mistovská díla ruské literatury“34, no ako mladík písal poéziu, neskôr prózu do zásuvky.

Tri texty venované spisovatelovi Fiodorovi Michajlovičovi Dostojevskému sú skromným záberom do nemalého počtu iných písomných priznaní sa $\mathrm{k}$ nemu a k pokusom porozumiet', zdôvodnit a obhájit jeho tvorbu, jeho spoločenský čas aj to, čím a ako si svoj všedný život aj svojou vôlou menil na náročný. Leonid Grossman mal kontakt s Annou Dostojevskou, poznali sa, dá sa predpokladat, že jeho koncept prijala a vyrovnala sa s postupným načrtávaním osobnostnej priepasti v mladosti ruského spisovatela, s ktorým sa nedokázal vyrovnat', a ona sama v ich vzţahu, voči jeho rodine a kultúrnej pospolitosti ho riešila, ako vládala a na čo mala prostriedky. Leonid Grossman autorsky ostáva voči téme a postave svojho literáta $\mathrm{v}$ zajatí faktu a jeho kontextu, ktorý sám pozná, kompozične vedome vystupuje z ich uzavretého zázemia, ked' mu neposkytujú viac podnetov, ako ich sám očakával. Prirodzene a oprávnene predpokladal, že sa pozornost̉ sústredí na jeho kultivované, pragmatické zachytenie Dostojevského stretu s cárskou mocou, na jeho roky vo väzení. Grossman túto udalost̉ nepreceňuje, pomocou reálií naznačuje, ako sa osobnostne ruský spisovatel zovrel až zavrel do duchovného boja za dobro, proti zlu, ale aj k rezervovanému vzţahu voči spoločenskému a kultúrnemu pohybu na kontinente.

32 Tamže, s. 188.

33 ŠEDIVÝ, Jakub: Doslov. In: CYPKIN, Leonid: Léto v Baden-Badenu. Op. cit., s. 199.

34 Tamže, s. 194. 
Manželka Anna Grigorievna zachytila spoločné roky ako oddaná, milujúca a nápomocná bytost̉ svojmu životnému partnerovi. V jej spomienkach je zaznamenaná „chvíla autentickej pravdy“ o tom, ako, prečo a s kým žil, sporil sa, komu ustupoval a prečo sa stal Dostojevský nerozhodný až vzt̉ahovačný, ale práve Anna Grigorievna natrvalo zanechala správu aj o tom, ako citová zúčastnenost na vztahu s talentovaným partnerom ju oberala o osobnú silu aj o emancipačné ambície jeho okolie. Spomienky Anny Dostojevskej majú v jej zámere, ved' ten primárne sledovala, poslanie povedat ženským okom pravdu o tom, čo spoločne žili. Azda aj preto sú jej Spomienky protipólom početných denníkov jej manžela, najskôr spoločne a vierohodne vypovedajú o čase, dobe, spoločnosti, prosto o živote, ktorý žili oni a žila aj ich krajina a kontinent. Leonid Cypkin uplatnil pôsobivú literárnu ambíciu pri téme a postave Dostojevského; presviedča ustáleným spôsobom narácie, že vie o osobnosti spisovatela dost̉ a naznačuje, čo s tým, čo vie o ňom dokáže premenit na rozprávačský zážitok. Cypkin, má na to výraznú osobnostnú motiváciu, skláňa sa pred mestom, v ktorom sa toho tak vela a pre tolkých stalo priestorom na zlo a dobro, na lásku aj nenávist', na povinnost’ a želanie, na presvedčenie, čo bolo možné jeho obyvatel'mi vykonat v ich životoch, teda iba to, na čo im okolnosti pridelili silu a schopnosti.

Od Grossmanovej ambície povedat všetko, o čom vie, Anny Dostojevskej pripomenutím toho, ako to v ich spoločnom živote bolo, aby sa pravda nevytratila z rozpomienok na spisovatela a nie vždy žičlivé Rusko voči jeho talentu, prináša Cypkinovo sugestívne rozprávanie najvýraznejší odstup od rekonštrukcie témy a postavy spisovatela. Vedome sa prikláňa $\mathrm{v}$ príbehu o spisovatelovi $\mathrm{k}$ aure mesta a krajiny, ktoré spoločne $\mathrm{v}$ dejinných reáliách dali svetu kultúry to, čím sa Dostojevskij zapísal do času a do umenia, ved’ iba ono, umenie, má tu danost', nepodliehat platným zákonitostiam času.

\section{Literatúra}

CYPKIN, Leonid: Léto v Baden-Badenu. (Leonid Tsypkin: Summer in Baden-Baden, 1981; Moskva, 2003). Překlad a doslov Jakub Šedivý. Praha: Prostor, 2015.

DOSTOJEVSKÁ, Anna Grigorievna: Spomienky. Prel. Mária Hulmanová. Bratislava: Európa, 2009.

GROSSMAN, Leonid: Dostojerskij. (Chudožestvennaja literatura. Moskva - Leningrad, 1932). Prel. Emília Drugová. Bratislava: Tatran, 1979.

Mejlach, Boris S.: Život Alexandra Puškina. (Chudožestvennaja literatura. Leningrad, 1974). Prel. Jozef Marušiak. Bratislava: Slovenský spisovatel', 1974.

PAUSTOVSKY, Konstantin: Zlatá ruža. Poznámky o spisovatelovej práci. (Sobranije sočinenija, tom 2. Moskva, 1957). Prel. Ružena Dvořáková-Žiaranová. Verše prebásnil Viliam Turčány. Doslov Umenim o umeni nap. Ondrej Marušiak. Bratislava: Slovenské vydavatel’stvo krásnej literatúry, 1963.

Slovnik ruských spisovatelů od počátků ruské literatury do roku 1971. Heslo Dostojevskij Fjodor Michajlovič. Praha: Lidové nakladatelství, 1972, s. 64-66. 
prof. PhDr. Viera Žemberová, CSc.

Filozofická fakulta, Prešovská univerzita v Prešove

17. novembra č. 1, 08078 Prešov, SK

viazember@gmail.com 